\title{
THE FECUNDITY OF PLAICE FROM THE SOUTH AND WEST COASTS OF IRELAND
}

\author{
By T. B. BAgENAL \\ The Marine Station Millport
}

(Text-figs. I-3)

This paper is the fifth in a series dealing with the fecundity of flatfish (Bagenal, I957 $a, b ; 1958,1960)$, and is concerned with the numbers of eggs in the roes of ripening female plaice Pleuronectes platess $\mathrm{L}$ L. caught off the south and west coasts of Ireland during November and December 1958. The fish were obtained from Wexford, Ballycotton, Schull, Dingle, Galway and Killybegs (Fig. I).

The fish were bought immediately after being landed either direct from the fishermen, when the whole female catch was obtained, or through An Bord Iascaigh Mhara when a predetermined number were taken as they lay in a fish box. The fish bought from the fishermen were ungutted, but those obtained from the Board had been gutted. A few of the latter fish had to be rejected as the ovaries were damaged, but it was an insignificant percentage. Thereafter the treatment of the fish, storage of the ovaries, the subsampling and counting of the eggs and the statistical analysis of the results were all as described in an earlier paper (Bagenal, 1957a) except that the four aliquot samples of eggs consisted of $\mathrm{I} / 4 \mathrm{IO}$ instead of $\mathrm{I} / 200$. This greatly reduced the time and labour of egg counting.

I would like to thank the employees of An Bord Iascaigh Mhara who helped me in Ireland and Miss Sheila Morris for her help in the laboratory.

\section{RESULTS}

The data are summarized in Tables $\mathrm{I}-3$, and the relation of fish length and fecundity are shown in Figs. 2 and 3 . The expected weight $(\hat{\mathrm{W}})$ and the expected fecundity $(\hat{\mathrm{F}})$ of a fish $37 \mathrm{~cm}$ long are also shown in Table $\mathrm{I}$. They were calculated from the regression equations of log length on log weight and on $\log$ fecundity, respectively, and may be used for comparing the different populations. The regression coefficients $(b)$ are also shown. (For details of the calculations see Bagenal, I957a.) Numerous tests were made to see if any of the differences in fecundity and condition were significant. 


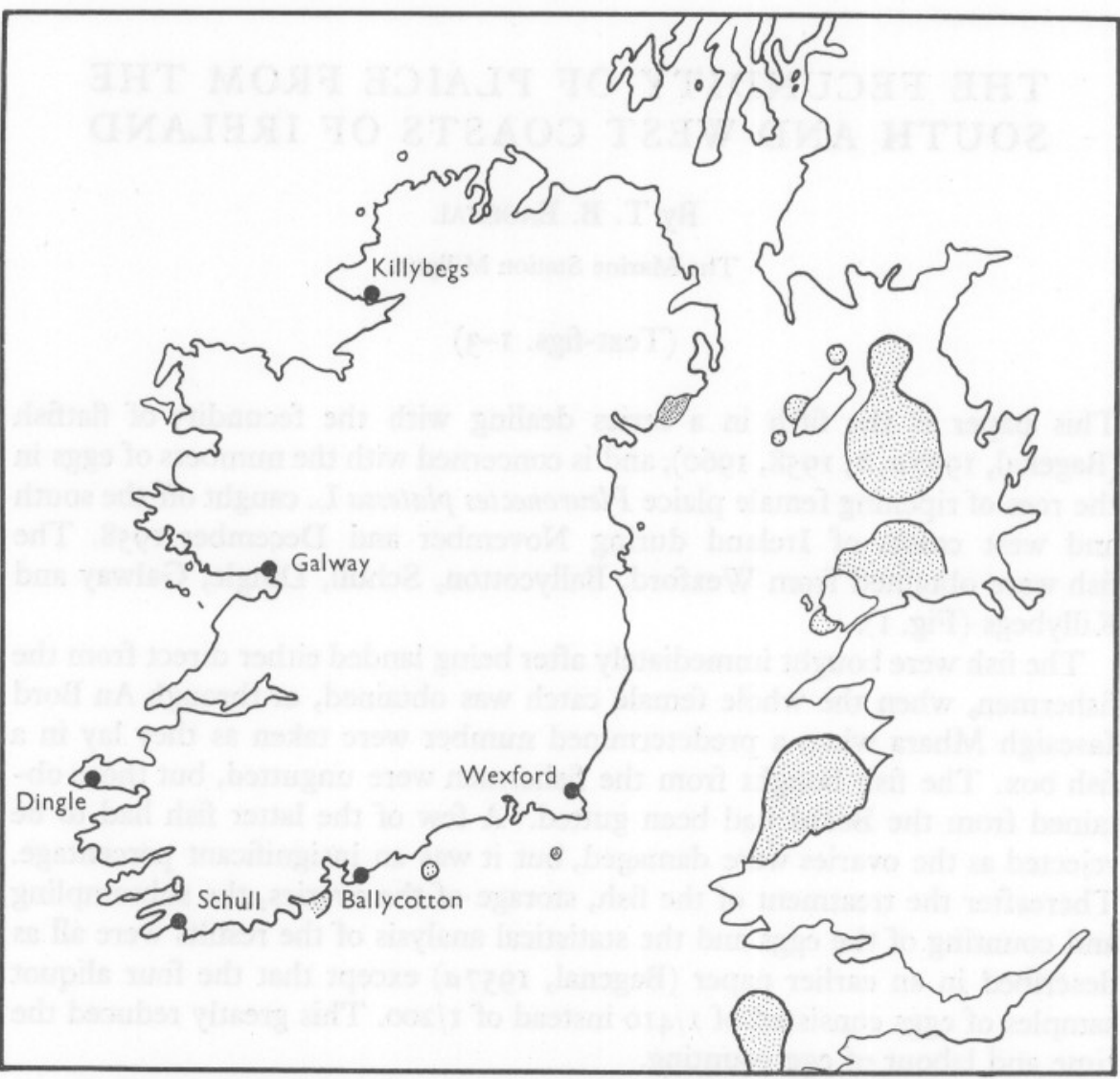

Fig. I. Map of Ireland and the Irish Sea, showing localities from which plaice were collected, and (stippled) the spawning areas found by Simpson.

\section{Wexford}

Simpson (1959b) made a survey of plaice eggs in 1952 and 1953 in the Irish and Celtic Seas from Newcastle (Co. Down) to west of Cork. He gives maps indicating the occurrence of newly spawned eggs. The largest concentration of eggs nearest to Wexford was found in Cardigan Bay (about 60 miles to the east across St George's Channel on the Welsh coast), and, although one egg was found south of Saltee Island, the Wexford plaice probably belong to the Cardigan Bay stock. The fecundity of the Wexford plaice was not found to differ from that of the Plymouth plaice (Bagenal, 1960) or from those of the Clyde (Bagenal, 1958) and appear to be similar to those in the Irish Sea for which Simpson (1957) has given the preliminary results. The plaice on the north-south line through the Clyde-Irish Sea-West Channel on longitude $5^{\circ}$ west have similar fecundities. 


\section{Ballycotton}

Simpson found one planktonic plaice egg off Minehead in 1955 (Survey I, 23 January-3 February). I found plaice very scarce at Ballycotton, 20 miles west. Their fecundity, however, was high.
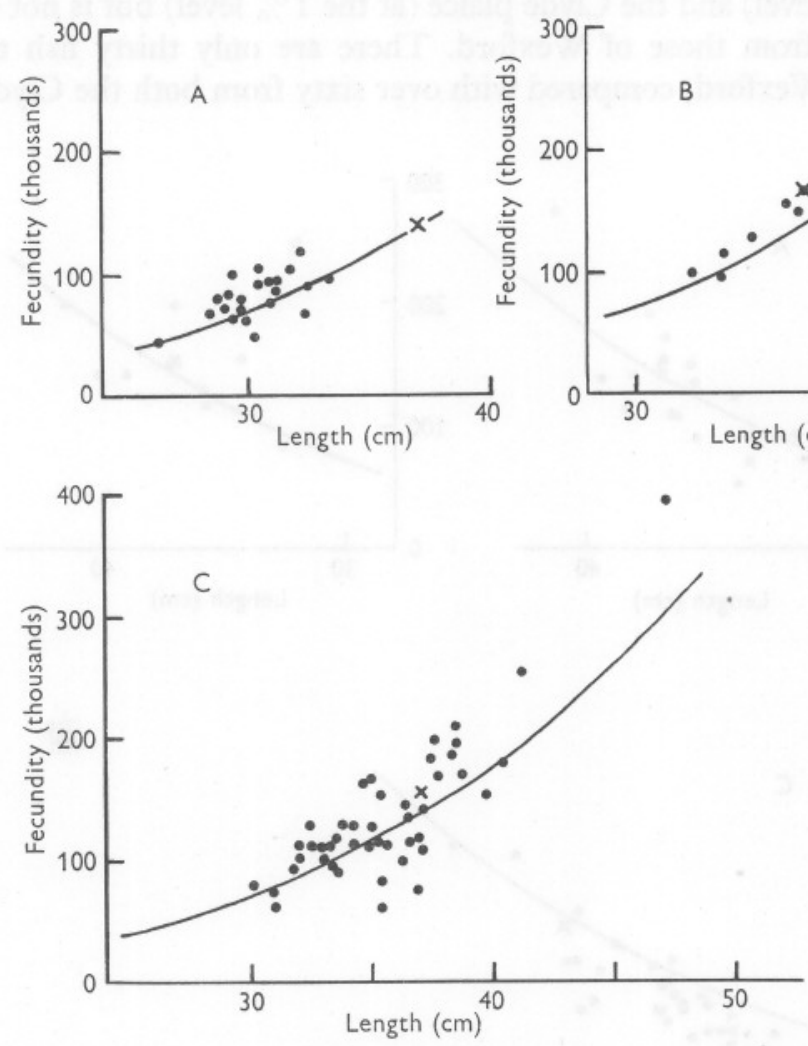

Fig. 2. Scatter diagrams showing the relation of fecundity and length of plaice from (A) Wexford, (B) Ballycotton and (C) Dingle. In some cases dots are superimposed on others. The expected fecundity $(\hat{\mathrm{F}})$ of fish of $37 \mathrm{~cm}$ is shown in each diagram by $\times$ and the calculated curve for Clyde fish is given for comparison.

\section{Schull}

West of Cork Simpson appears to have found the edge of a concentration of plaice eggs whose centre lay farther still to the west. At Schull, plaice were again scarce and only ten could be got in a reasonable time. Even though the Schull and Ballycotton plaice have very high fecundities, they are not statistically significantly different from those of Wexford, but the samples are unfortunately very small. 


\section{Dingle}

At Dingle, plaice were plentiful and the roes from a good sample of fifty fish were easily obtained. These, like those from Schull, have a high fecundity. Their fecundity is significantly higher than that of Plymouth fish (at the $5 \%$ probability level) and the Clyde plaice (at the I \% level) but is not statistically different from those of Wexford. There are only thirty fish to test them against at Wexford, compared with over sixty from both the Clyde and Plymouth.
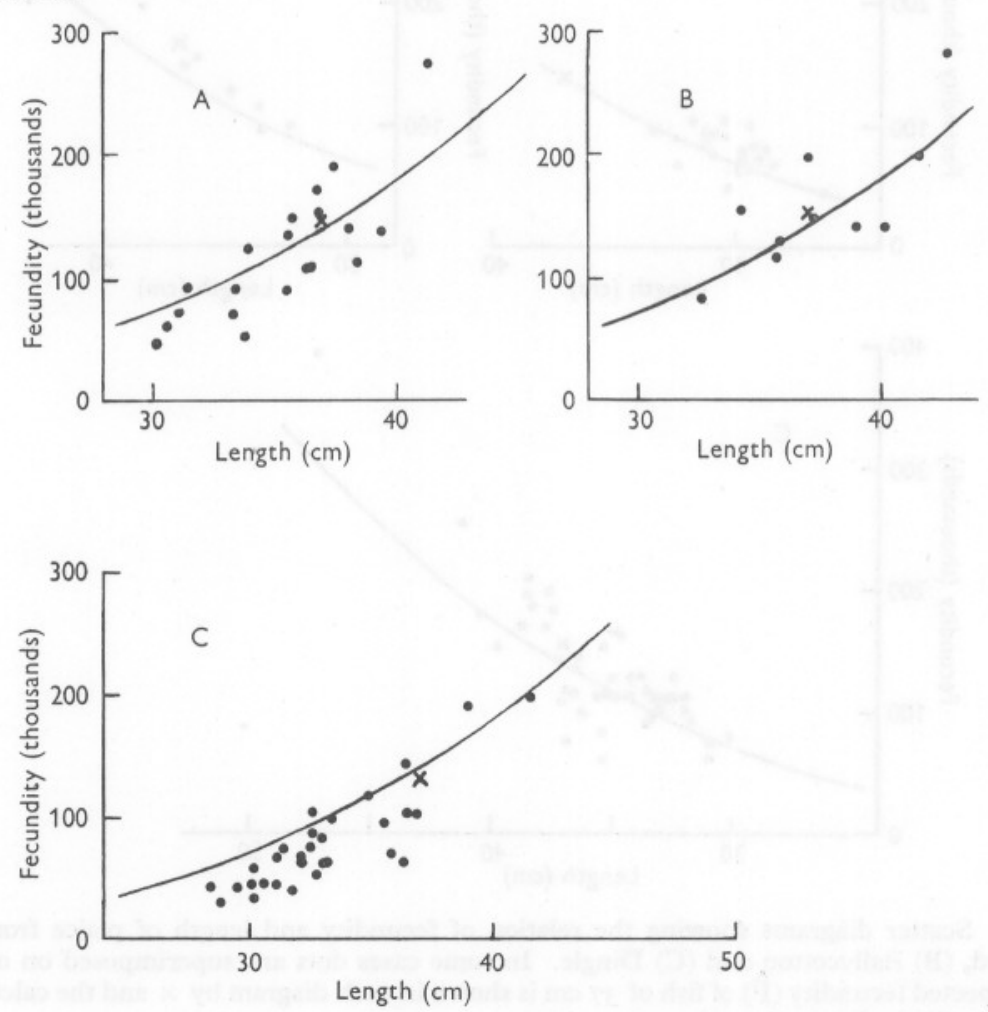

Fig. 3. Scatter diagrams showing the relation of fecundity and length of plaice from (A) Galway and (B) Schull and (C) Killybegs. In some cases dots are superimposed on others. The expected fecundity $(\hat{\mathrm{F}})$ of fish of $37 \mathrm{~cm}$ is shown in each diagram by $\times$ and the calculated curve for Clyde plaice is given for comparison.

\section{Galway}

The Galway plaice were caught off Clare Island. Their fecundity is lower than that of the Dingle fish, but the difference is not statistically significant. 
TABLE 1. SUMMARY OF IRISH PLAICE FECUNDITY DATA

\begin{tabular}{|c|c|c|c|c|c|c|}
\hline & Wexford & $\begin{array}{l}\text { Bally- } \\
\text { cotton }\end{array}$ & Schull & Dingle & Galway & Killybegs \\
\hline $\begin{array}{l}\text { Number of fish } \\
\text { Mean length }(\mathrm{cm}) \\
\text { Mean weight }(\mathrm{gr}) \\
\text { Mean age (years) } \\
\text { Mean fecundity } \\
\text { W for } 37 \mathrm{~cm} \\
\text { F for } 37 \mathrm{~cm}\end{array}$ & $\begin{array}{l}30 \\
30 \cdot 67 \\
292 \cdot 63 \\
2 \cdot 9 \\
84,002 \\
505 \cdot 3 \\
139,612\end{array}$ & $\begin{array}{l}8 \\
35 \cdot 40 \\
458 \cdot 50 \\
3 \cdot 3 \\
139,336 \\
539 \cdot 2 \\
169,342\end{array}$ & $\begin{array}{l}10 \\
37 \cdot 59 \\
549 \cdot 90 \\
2 \cdot 8 \\
158,137 \\
523 \cdot 8 \\
150,641\end{array}$ & $\begin{array}{l}50 \\
35 \cdot 51 \\
483 \cdot 56 \\
3 \cdot 1 \\
133,195 \\
549 \cdot 4 \\
152,775\end{array}$ & $\begin{array}{l}20 \\
35 \cdot 41 \\
464 \cdot 70 \\
3 \cdot 2 \\
120,811 \\
521 \cdot 4 \\
146,182\end{array}$ & $\begin{array}{l}31 \\
33 \cdot 17 \\
358 \cdot 52 \\
3 \cdot 8 \\
82,162 \\
501 \cdot 2 \\
132,120\end{array}$ \\
\hline $\begin{array}{l}\text { Regression } \\
\text { coefficient (b) }\end{array}$ & $2 \cdot 71$ & $4 \cdot 15$ & $3 \cdot 10$ & 3.33 & $4 \cdot 33$ & $4 \cdot 35$ \\
\hline
\end{tabular}

TABLE 2. THE MEAN FECUNDITY (IN THOUSANDS) OF EACH 3 CM LENGTH-GROUP OF IRISH FEMALE PLAICE

\begin{tabular}{|c|c|c|c|c|c|c|}
\hline \multirow{2}{*}{$\begin{array}{l}\text { Length } \\
\text { group }\end{array}$} & \multicolumn{2}{|c|}{ Wexford } & \multicolumn{2}{|c|}{ Ballycotton } & \multicolumn{2}{|c|}{ Schull } \\
\hline & No. & Fecundity & No. & Fecundity & No. & Fecundity \\
\hline 27 & I & $45 \cdot 72$ & - & - & - & 二 \\
\hline 30 & $2 \mathrm{I}$ & $8 \mathrm{r} \cdot 39$ & $\overline{3}$ & $\overline{104 \cdot 76}$ & - & $\overline{1} \overline{6} 6.65$ \\
\hline $\begin{array}{l}33 \\
36\end{array}$ & 8 & 95.63 & $\begin{array}{l}3 \\
4\end{array}$ & $\begin{array}{l}104.76 \\
\text { I } 50.42\end{array}$ & $\begin{array}{l}2 \\
4\end{array}$ & $\begin{array}{l}116.65 \\
146.19\end{array}$ \\
\hline 36 & 二 & $\bar{z}$ & $\begin{array}{l}4 \\
\mathrm{I}\end{array}$ & 198.75 & ${ }_{2}^{4}$ & $\begin{array}{l}146.19 \\
140.48\end{array}$ \\
\hline $\begin{array}{l}39 \\
42\end{array}$ & 二 & 二 & - & - & 2 & $24 I \cdot I 8$ \\
\hline 45 & - & - & - & - & - & - \\
\hline \multirow{3}{*}{$\begin{array}{l}\text { Length } \\
\text { group }\end{array}$} & \multicolumn{2}{|c|}{ Dingle } & \multicolumn{2}{|c|}{ Galway } & \multicolumn{2}{|c|}{ Killybegs } \\
\hline & & & & & & \\
\hline & No. & Fecundity & No. & Fecundity & No. & Fecundity \\
\hline 27 & - & - & - & - & - & - \\
\hline 30 & 3 & $70 \cdot 42$ & 3 & 60.92 & 9 & $\begin{array}{l}47 \cdot 83 \\
78 \cdot 2 I\end{array}$ \\
\hline 33 & 17 & I07.77 & 5 & $87 \cdot 74$ & 13 & $\begin{array}{r}78 \cdot 21 \\
\text { IOI.08 }\end{array}$ \\
\hline 36 & I9 & $\begin{array}{l}122.98 \\
181.57\end{array}$ & 7 & I32.II & $\begin{array}{l}7 \\
1\end{array}$ & $\begin{array}{l}\text { IOI.08 } \\
\text { I92.60 }\end{array}$ \\
\hline $\begin{array}{l}39 \\
42\end{array}$ & $\begin{array}{l}8 \\
2\end{array}$ & $\begin{array}{l}\text { I8r.57 } \\
216 \cdot 17\end{array}$ & $\begin{array}{l}4 \\
\mathrm{I}\end{array}$ & $\begin{array}{l}148 \cdot 04 \\
277.88\end{array}$ & I & $\begin{array}{l}199.67 \\
\text { I }\end{array}$ \\
\hline 45 & - & & - & - & - & - \\
\hline 48 & I & $394 \cdot 83$ & - & - & - & - \\
\hline
\end{tabular}

TABLE 3. THE MEAN FECUNDITY AND LENGTH OF EACH AGE-GROUP OF FEMALE PLAICE CAUGHT OFF SOUTH AND WEST IRELAND

\begin{tabular}{|c|c|c|c|c|c|c|c|c|c|}
\hline \multirow[b]{2}{*}{$\begin{array}{l}\text { Age } \\
\text { group }\end{array}$} & \multicolumn{3}{|c|}{ Wexford } & \multicolumn{3}{|c|}{ Ballycotton } & \multicolumn{3}{|c|}{ Schull } \\
\hline & No. & $\begin{array}{l}\text { Mean } \\
\text { length }\end{array}$ & $\begin{array}{c}\text { Mean } \\
\text { fecundity }\end{array}$ & No. & $\begin{array}{l}\text { Mean } \\
\text { length }\end{array}$ & $\begin{array}{c}\text { Mean } \\
\text { fecundity }\end{array}$ & No. & $\begin{array}{l}\text { Mean } \\
\text { length }\end{array}$ & $\begin{array}{c}\text { Mean } \\
\text { fecundity }\end{array}$ \\
\hline II & 6 & $3 \mathrm{I} \cdot 4$ & I03. 6 & - & - & - & 3 & $35^{\circ} 8$ & II 5.8 \\
\hline $\begin{array}{l}\text { III } \\
\text { IV }\end{array}$ & $2 \mathrm{I}$ & & & 4 & & 117.5 & 5 & & \\
\hline $\begin{array}{l}\text { IV } \\
\text { V }\end{array}$ & 3 & $3 I \cdot I$ & $76 \cdot 2$ & 2 & $35 \cdot 8$ & 139.8 & I & $37^{\circ} 0$ & $198 \cdot 0$ \\
\hline VI & - & - & - & - & 二 & - & 二 & 二 & 二 \\
\hline VII & 二 & 二 & - & 二 & 二 & - & 二 & 二 & 二 \\
\hline \multirow[t]{2}{*}{ VIII } & - & - & - & - & - & - & - & - & - \\
\hline & \multicolumn{3}{|c|}{ Dingle } & \multicolumn{3}{|c|}{ Galway } & \multicolumn{3}{|c|}{ Killybegs } \\
\hline $\begin{array}{l}\text { Age } \\
\text { group }\end{array}$ & No. & $\begin{array}{l}\text { Mean } \\
\text { length }\end{array}$ & $\begin{array}{c}\text { Mean } \\
\text { fecundity }\end{array}$ & No. & $\begin{array}{l}\text { Mean } \\
\text { length }\end{array}$ & $\begin{array}{c}\text { Mean } \\
\text { fecundity }\end{array}$ & No. & $\begin{array}{l}\text { Mean } \\
\text { length }\end{array}$ & $\begin{array}{c}\text { Mean } \\
\text { fecundity }\end{array}$ \\
\hline II & I6 & $33 \cdot 2$ & $109 \cdot 2$ & 4 & $34 \cdot 0$ & 96.5 & 3 & $30 \cdot 6$ & $6 \mathrm{r} \cdot 5$ \\
\hline III & I8 & & & Io & & & 12 & & \\
\hline IV & Io & 37 & I & 4 & & 196 & 9 & & $93 \cdot 3$ \\
\hline $\mathrm{V}$ & I & & & 2 & $38 \cdot 4$ & $129^{\circ} 0$ & 3 & & \\
\hline VI & I & $35 \cdot 2$ & 122 & - & - & - & 3 & & I24.7 \\
\hline VII & - & & - & - & - & - & I & $4 \mathrm{r} \cdot 6$ & II $9 \cdot 7$ \\
\hline VIII & I & $47 \cdot 3$ & 394.8 & - & - & - & - & - & - \\
\hline
\end{tabular}




\section{Killybegs}

Thirty-one female plaice were sampled at Killybegs, the fish having been caught in Donegal Bay. The fecundity is lower than at Galway, and significantly lower at the I \% level than the fecundity of the Dingle fish, but the mean fecundity of the Killybegs plaice does not differ significantly from the Clyde fish, though the slopes of the lines $(b=3.21$ for the Clyde and 4.35 for Killybegs) are nearly significantly different at the $5 \%$ level.

\section{DISCUSSION}

The fecundity of plaice increases westwards along the south coast to Dingle and then decreases northwards along the west coast to Killybegs. Added to these general trends there is a further feature that small populations of plaice which are living in 'bleak' habitats appear to have a higher fecundity than neighbouring larger populations. This is seen at Ballycotton and Schull, as well as at Lyme Bay (Bagenal, 1960). The mechanism behind these differences in fecundity is still obscure, but the survival value of them is quite clear. Dingle and Schull, being in the south-west of Ireland, are not only in an extremely exposed region, but also are in the track of the prevailing southwesterly winds and currents. There will therefore be a much greater chance of the planktonic eggs and young being transported long distances, than for example in the North Sea. Similarly, in small populations the dispersal of the planktonic eggs and larvae may at times be catastrophic. In both cases a high fecundity will increase the chances of sufficient of the progeny being able to return to the breeding area. This view implies that the fish return to the area where they themselves were spawned regardless of their movements in the meantime.

A similar explanation (Bagenal, 1960) has been put forward for the higher fecundities that have been found with Flamborough and Rye Bay plaice, both of which are small outliers of the main North Sea population. The North Sea plaice that spawn to the south of the Dogger Bank, and particularly the largest concentration in the Southern Bight (Simpson, I959a, fig. 35), have the lowest fecundities that have been recorded for this species (Simpson, 195I), and this is a relatively sheltered and enclosed area.

A further point of significance is the ranked order of fecundity and condition. For the Irish data given in Table I, the ranks are

\begin{tabular}{llll}
\multicolumn{1}{c}{ Condition } & \multicolumn{2}{c}{ Fecundity } \\
Dingle & 549 & Ballycotton & I69 \\
Ballycotton & 539 & Dingle & 153 \\
Schull & 524 & Schull & 15 \\
Galway & $52 \mathrm{I}$ & Galway & I46 \\
Wexford & 505 & Wexford & 140 \\
Killybegs & 501 & Killybegs & I32
\end{tabular}


The ranked order for fecundity and condition of fish including data from other British areas is given below.

\begin{tabular}{ll}
\multicolumn{2}{c}{ Condition } \\
Lyme Bay & $66 \mathrm{I}$ \\
Dingle & 549 \\
Ballycotton & 539 \\
Clyde & 526 \\
Schull & 524 \\
Galway & 521 \\
North Sea & $5 \mathrm{I} 7$ \\
Plymouth & $5 \mathrm{I} 6$ \\
Wexford & 505 \\
Killybegs & 501 \\
Rye Bay & $47 \mathrm{I}$
\end{tabular}

\begin{tabular}{ll}
\multicolumn{1}{c}{ Fecundity } \\
Lyme Bay & 244 \\
Ballycotton & I69 \\
Dingle & I53 \\
Schull & 15I \\
Galway & 146 \\
Wexford & 140 \\
Plymouth & $137 \cdot 5$ \\
Clyde & $137 \cdot 3$ \\
Killybegs & 132 \\
Rye Bay & 127 \\
North Sea & 84
\end{tabular}

The difference here, apart from the interchange of positions by Ballycotton and Dingle, and by Wexford and Plymouth, are due to Clyde and North Sea being four places higher in the fecundity rank. The most likely reason for the greater weight of these fish is that they were probably caught earlier in the year, that is, a longer time before the spawning season. As the time of spawning approaches the condition of the somatic tissue decreases very rapidly though the gonads of course are increasing in weight. It is for this reason that I attach little importance to the weight of the fish or their gonads in fecundity work (cf. Kändler, I959), unless the spawning season is well known. That these weights are important factors to be considered if the spawning dates are known is obvious, and they may be useful when comparing two nearby localities at nearly the same time. In this case the fish will probably be at comparable stages in their breeding development. This, I think, is true of the Irish data.

Another point that is apparent from Table 3 is that the growth rate also increases along the south coast, and decreases again northwards. At Dingle the mean length of eighteen fish in the III age-group was $35.3 \mathrm{~cm}$, though in the North Sea plaice often do not reach this length until their sixth year. The order of localities ranked for the rate of growth of fish is not the same as for condition or fecundity, though as has been found elsewhere (Simpson, I95I; Bagenal, 1958) the fast growing fish do tend to be those with the higher fecundity.

\section{SUMMARY}

The fecundity of plaice from six localities on the south and west coasts of Ireland has been analysed. For a $37 \mathrm{~cm}$ fish the fecundity increases from about I40 thousand eggs at Wexford to I 53 thousand eggs at Dingle, and decreases northwards to $\mathrm{I} 32$ thousand at Killybegs, though at Ballycotton and Schull where plaice are scarce the fecundity is unusually high. It is suggested that the fecundity is an adaptive character, being highest in the poorer habitats and in regions where the dispersal of the planktonic stages will be greatest. This 
implies that plaice, like other fish, return to an hereditary spawning area. In the poor habitats the fish have to be in good condition, grow fast and have a high fecundity in order to survive.

\section{REFERENCES}

BAgENAL, T. B., I957 $a$. The breeding and fecundity of the Long Rough dab Hippoglossoides platessoides (Fabr.) and the associated cycle in condition. F. mar. biol. Ass. U.K., Vol. 36, pp. 339-73.

- 1957b. Annual variations in fish fecundity. F. mar. biol. Ass. U.K., Vol. 36, pp. $377-82$.

— 1958. The fecundity of Clyde plaice. F. mar. biol. Ass. U.K., Vol. 37, pp. 309I3.

— I960. The fecundity of English Channel plaice. F. mar. biol. Ass. U.K., Vol. 39, pp. 249-54.

KäNDLER, R., I959. UUber die Fruchtbarkeit der Scholle im Kattegat. Kieler Meeresforsch., Bd. 15, pp. 29-33.

Simpson, A. C., I95I. The fecundity of the plaice. Fish. Invest., Lond., Ser. 2, Vol. I7, No. 5, 27 pp.

- 1957. The spawning of the plaice (Pleuronectes platessa) in the Irish Sea. Paper No. 54 read at the annual meeting of I.C.E.S., Bergen, I957.

- I959 $a$. The spawning of the plaice in the North Sea. Fish. Invest., Lond., Ser. 2, Vol. 22, No. 7, III pp.

$(1959 b)$. The spawning of the plaice (Pleuronectes platessa) in the Irish Sea. Fish. Invest., Lond., Ser. 2, Vol. 22, No. 8, 30 pp. 